\title{
Microbial Inoculants Development for Bioremediation of Gasoline and Diesel Contaminated Soil
}

\author{
Aline Jaime Leal' ${ }^{1}$ Edmo Montes Rodrigues ${ }^{2}$, Rita de Cássia Rocha Fernandes ${ }^{2}$, \\ Arnaldo Chaer Borges ${ }^{2}$, Aline Daniela Lopes Júlio², Fernanda de Souza Freitas ${ }^{2}$, \\ Marcos Rogério Tótola2\# \\ ${ }^{1}$ Federal Institute Sul-rio-Grandense, Bagé, Rio Grande do Sul, Brazil \\ ${ }^{2}$ Laboratory of Environmental Biotechnology and Biodiversity, Microbiology Department Federal University of Viçosa, Viçosa, \\ Minas Gerais, Brazil \\ Email: *edmomontes@yahoo.com.br, "totolaufv@gmail.com
}

How to cite this paper: Leal, A.J., Rodrigues, E.M., Fernandes, R.C.R., Borges, A.C., Júlio, A.D.L., Freitas, F.S. and Tótola, M.R. (2018) Microbial Inoculants Development for Bioremediation of Gasoline and Diesel Contaminated Soil. Open Access Library Journal, 5: e4449.

https://doi.org/10.4236/oalib.1104449

Received: February 27, 2018

Accepted: April 5, 2018

Published: April 8, 2018

Copyright ( 2018 by authors and Open Access Library Inc.

This work is licensed under the Creative Commons Attribution International License (CC BY 4.0).

http://creativecommons.org/licenses/by/4.0/

\section{(c) () Open Access}

\begin{abstract}
In this study, we describe the development of microbial inoculants for the bioremediation of hydrocarbon-contaminated soils through the enrichment of hydrocarbonoclastic populations in municipal solid waste compost (MSWC). Respirometric analyses were performed along with quantification of total heterotrophic bacteria and ester-linked fatty acid methyl ester (EL-FAME) profiling of the microbial communities of the inoculants. $\mathrm{CO}_{2}$-emission rate increased sharply when the compost received application of water plus gasoline or diesel. After 8 (compost + diesel) and 12 days (compost + gasoline), we observed a significant increase in the number of heterotrophic bacteria. In inoculants receiving gasoline, FAME markers of fungi predominated throughout the incubation period (18 days). By the end of the incubation period, an increase in FAMEmarker for gram-positive bacteria and a decrease for gram-negative bacteria and actinobacteria were observed. In biodegradation trials (data not shown), the inoculants were very efficient, removing over $99 \%$ of hydrocarbons from a heavy soil ( $73 \%$ clay) contaminated with either diesel or gasoline $\left(17,000 \mathrm{mg} \cdot \mathrm{Kg}^{-1}\right.$ and $15,000 \mathrm{mg} \cdot \mathrm{Kg}^{-1}$, respectively). Inoculants based on MSWC enriched in hydrocarbonoclastic microorganisms may be an effective alternative to improve bioremediation in hydrocarbon-contaminated soils.
\end{abstract}

\section{Subject Areas}

Ecology, Environmental Sciences, Microbiology, Soil Science 


\section{Keywords}

Bioremediation, Hydrocarbon Degradation, Inoculant Development, Soil

Contamination

\section{Introduction}

Bioremediation has been applied to accelerate the biodegradation of contaminants and rehabilitate the contaminated environment to a condition similar to that found before contamination, either in terms of biodiversity or ecosystem functions [1]-[6]. Some approaches can be adopted to ensure proper biological activity during the bioremediation process, including biostimulation (by eliminating environmental limitations, including low availability of mineral nutrients, water, and electron acceptors, extremes of $\mathrm{pH}$ or temperature, etc); bioaugmentation (inoculation with selected microorganisms efficient in biodegradation of target contaminants), and application of surfactants or biosurfactants-producing microorganisms to increase the bioavailability of contaminants [2]-[12].

The use of bioaugmentation generates much contradiction between the researches. Some studies have demonstrated that biodegradation is accelerated by inoculation [5] [8] [13] [14], while others show neutral or even negative effects [15] [16] [17]. However, it must be emphasized, that the efficacy of the abovementioned bioremediation strategies depends on particularities of the target environment and, in several cases, they can act as complementary techniques [3] [18]. The microbial species and isolates may have positive or negative effect on biodegradation, depending on the combination of microorganisms used [14]. The success of bioaugmentation depends on the use of suitable microorganisms and their survival and activity in the target habitat.

In this study, the enrichment of hydrocarbonoclastic microbial populations was conducted under uncontrolled environmental variables such as temperature and humidity, in order to favor the selection of populations with higher adaptability to environmental variables that affect the survival and biodegradation activity. Moreover, we performed enrichment of a mixed microbial population without isolation in culture media. It was considered, for the adoption of this strategy, that uncultivable microorganisms can also play a role in hydrocarbon biodegradation.

In recent studies, the use of organic waste in biostimulation and bioaugmentation of soils contaminated with hydrocarbons hasproduced satisfactory results [18] [19] [20]. Therefore, in the present work, we proposed the use of municipal solid waste compost (MSWC) for the development of microbial inoculants capable of degrading gasoline and diesel in the soil. This residue was selected owing to its desirable characteristics to microbial inoculants, such as high microbial diversity and high capacity to adsorb hydrocarbons, which can prevent volatilization of n-alkanes of low molecular weight; it is a biologically stable material 
consisting of humic substances and a solid matrix, with a low C:N ratio [21] [22]. The above mentioned aspects make MSWC a good conditioner of soils [23], improving its physical, chemical, and biological properties. Thus, the material can function as a suitable substrate for the development of inoculants for use in contaminated soils.

\section{Material and Methods}

\subsection{Substrate for the Development of Inoculants}

The substrate used for the development of inoculants was MSWC obtained from the composting facility of the municipality of Coimbra, MG, Brazil. The compost was sieved through a $5-\mathrm{mm}$ sieve and analyzed for its physical and chemical properties (Table 1).

\subsection{Concentration of Gasoline and Diesel to Be Added to MSWC}

The concentration of gasoline and diesel suitable for enrichment of hydrocarbonoclastic microbial populations was determined by applying these fuels to MSWC in doses of $7500,15,000$, and $37,500 \mathrm{mg} \cdot \mathrm{Kg}^{-1}$ dry weight for gasoline and $8500,17,000$, and $42,650 \mathrm{mg} \cdot \mathrm{Kg}^{-1}$ dry weight for diesel. The material was mixed with a spatula and analyzed for $\mathrm{CO}_{2}$ evolution in a respirometer equipped with an infrared detector with intermittent air flow (Sable System, NE, USA). The MSWC received new applications of fuels every 5 days, at the same initial concentrations. The influence of moisture on the biodegradation of hydrocarbons was evaluated under two humidity conditions: no moisture adjustment and moisture fixed at $60 \%$ of the water-holding capacity (WHC). Subsequent moisture adjustments of the least treatment were made when the moisture content reached 40\% WHC. The C: N: P ratio was adjusted with ammonium sulfate to 100:10:2. The microcosms were incubated at $30^{\circ} \mathrm{C}$ for 14 days without stirring. Compost not receiving gasoline or diesel was used as control. The experimental design was a completely randomized $4 \times 2$ factorial for each source of hydrocarbon (four doses of gasoline or diesel and two moisture level), with three replicates for each treatment.

Table 1. Physical and chemical properties of the municipal solid waste compost used as substrate for the production of microbial inoculants.

\begin{tabular}{cccc}
\hline Parameter & Value & Heavy Metals & Value \\
\hline Humidity (\%) & 24.78 & $\mathrm{Cd}\left(\mathrm{mg} \cdot \mathrm{kg}^{-1}\right)$ & 3.29 \\
$\mathrm{WHC}^{\dagger}(\%)$ & 59.62 & $\mathrm{Cr}\left(\mathrm{mg} \cdot \mathrm{kg}^{-1}\right)$ & 31.80 \\
$\mathrm{pH}$ & 8.5 & $\mathrm{~Pb}\left(\mathrm{mg} \cdot \mathrm{kg}^{-1}\right)$ & 51.25 \\
$\mathrm{OM}^{\dagger}(\%)$ & 19.32 & $\mathrm{Ni}\left(\mathrm{mg} \cdot \mathrm{kg}^{-1}\right)$ & 22.07 \\
$\mathrm{Org} . \mathrm{C}^{\dagger}(\%)$ & 4.83 & & \\
$\mathrm{P}(\%)$ & 0.47 & & \\
$\mathrm{~N}(\%)$ & 1.16 & &
\end{tabular}

${ }^{\dagger}$ Water holding capacity (WHC); Organic Matter (OM); Organic Carbon (Org. C). 


\subsection{Inoculants Development}

During the development of the inoculants, two intervals of hydrocarbon addition (as gasoline or diesel) were tested for each fuel after the initial application (Table 2). We adopted a smaller interval for gasoline, since it is composed mainly of lighter hydrocarbons, supposedly more volatile and more easily biodegradable than diesel. The dose of gasoline or diesel was fixed at 37,500 and $42,650 \mathrm{mg} \cdot \mathrm{kg}^{-1}$, respectively. The C: N: P ratio was corrected to 100:10:2, and the humidity was maintained at $40 \%-60 \%$ of the WHC. Each treatment was conducted in triplicates with $2000 \mathrm{~g}$ of matured compost/plot. The compost was incubated in plastic trays and incubated in an open environment away from sunlight. The temperature was recorded, and the compost was mixed by turning daily. The control treatment consisted of compost without application of hydrocarbons.

\subsection{Inoculants Analysis}

Ester-linked fatty acid methyl ester (EL-FAME) analysis was performed in according to (described at the subsection Ester-linked fatty acid methyl ester (EL-FAME) analysis) at $0,3,6,12$, and 18 days for inoculants amended with gasoline. For diesel-amended inoculants, it was not possible to remove the interference of hydrocarbons on the analysis of FAME and thus the EL-FAME profiles of these treatments are not reported. The sampling was performed prior to the additions of fresh gasoline (except at day zero, when the samples were collected immediately after applying the fuel). Samples for evaluation of the density of heterotrophic populations were collected at 2, 3, 6, 12, and 18 days for gasoline treatments and at $2,4,8,16$, and 24 days for diesel treatments. Sampling was performed before fresh addition of fuels.

Table 2. Frequency of application of gasoline and diesel for the development of microbial inoculants.

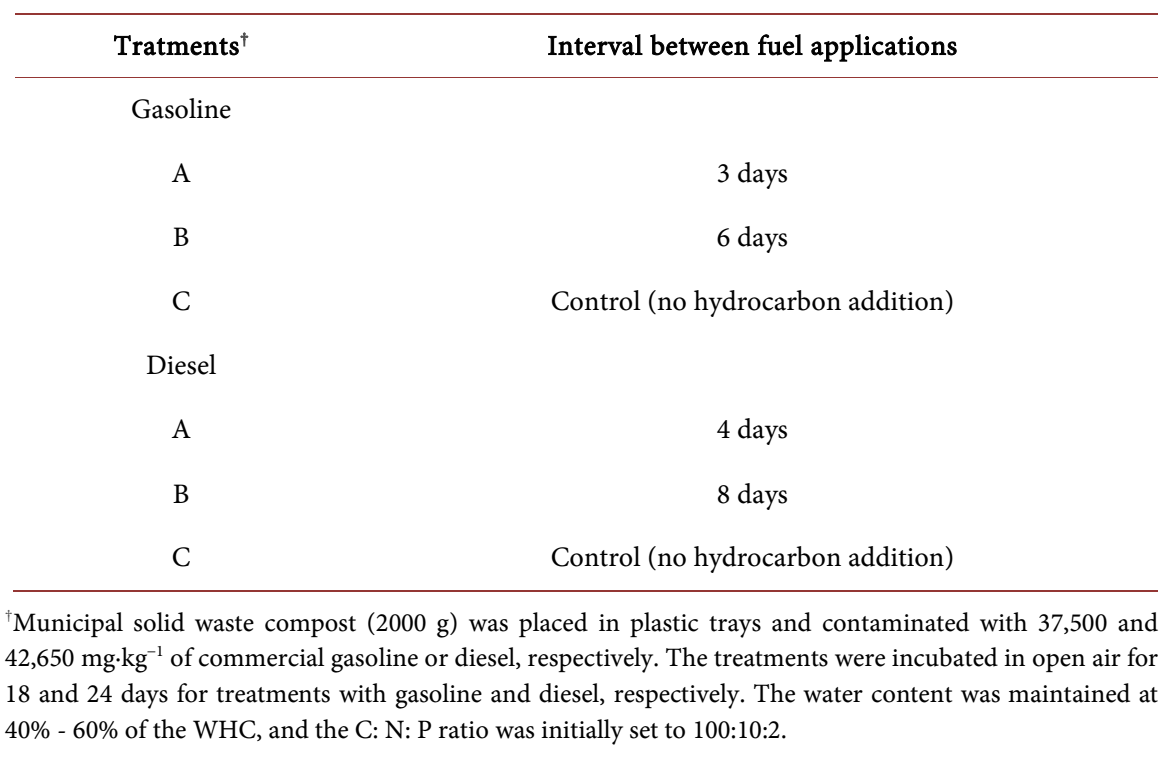




\subsection{Enumeration of Cultivable Bacterial Populations}

$10 \mathrm{~g}$ of each inoculum were diluted in $95 \mathrm{~mL}$ of sodium pyrophosphate $0.1 \%$ $(\mathrm{w} / \mathrm{v})$. After shaking at $200 \mathrm{rpm}$ for $20 \mathrm{~min}$ in room temperature, serial dilutions of the inoculum were plated on nutrient agar (HIMEDIA ${ }^{\circ}$ ) containing cycloheximide $\left(50 \mathrm{mg} \cdot \mathrm{L}^{-1}\right)$ to inhibit fungal growth and incubated at $30^{\circ} \mathrm{C}$ until the counting of colonies. This analysis was performed from the second day of the start of production of inoculants. ANOVA and t-student test (5\% probability) were the statistical methods employed on the analysis of data.

\subsection{Ester-Linked Fatty Acid Methyl Ester (EL-FAME) Analysis}

Before extraction and analysis of EL-FAME to describe the microbial communities of the inoculants, we developed a method to eliminate the interference of hydrocarbons in the samples. For this purpose, to each sample $(1 \mathrm{~g}$ fresh weight), $3 \mathrm{~mL}$ of sterile distilled water and $1 \mathrm{~mL}$ of hexane were added. After vigorous vortexing, the samples were centrifuged at $544 \times g$ for $15 \mathrm{~min}$. Immediately afterwards, the non-polar phase containing hydrocarbons was removed, followed by removal of the water phase. Water was used only to separate the compost from hexane. This process was repeated three times.

EL-FAMEs were extracted according to the method proposed by Shutter and Dick's (2000) [24], with slight modifications. A reduction of $2 / 3$ of the volume of reagents and samples was performed. In the last step, the solvent containing the FAMEs was evaporated under vacuum until complete dryness, and the residue was resuspended in $1 / 3$ of the original volume. The extracts were analyzed by using anAgilent Technologies 7890 gas chromatograph. The identification of fatty acids was done by the Sherlock Microbial Identification System (MIDI, Newark, DE, USA), using the reference libraries ITSA 1.0', IR2A1', or RTSBA6 . These system provides the dendogram from Euclidean Distance analysis of obtained data. Fatty acids markers of microbial groups are listed in Table 3.

\section{Results}

\subsection{Respirometric Analysis}

We used respirometric analysis to determine the most appropriate dose of gasoline or diesel for use in the production of inoculants. A significant interaction

Table 3. Fatty acids markers used in determining microbial groups present in inoculants.

\begin{tabular}{|c|c|c|}
\hline Markers Fatty Acids & Microbial Groups & References \\
\hline $17: 1 \omega 8 c ; 16: 1 \omega 5 c$ & Gram-negative bacteria & {$[25][26]$} \\
\hline i/a15:00; i16:00; i/a17:00 & Gram-positive bacteria & [25] [27] \\
\hline 10Me17:00; 10Me18:0 & Actinobacteria & [25] [28] \\
\hline 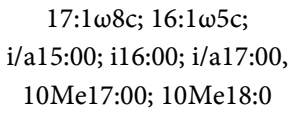 & Total bacteria & {$[25][26][27][28][29]$} \\
\hline $18: 1 \omega 9 \mathrm{c}$ & Fungi & {$[27]$} \\
\hline
\end{tabular}


was noted between the concentration of fuels and moisture $(p<0.05)$. The highest $\mathrm{CO}_{2}$ emissions were obtained in treatments with moisture content maintained at $40 \%-60 \%$ of the WHC (Figure 1 and Figure 2).

The response of the microbial community of the MSWC to the addition of hydrocarbons was more pronounced for diesel than for gasoline. $\mathrm{CO}_{2}$ production rate increased considerably at every episode of hydrocarbon addition and moisture adjustment (Figure 1(a) and Figure 2(a)). The effect of dose of either

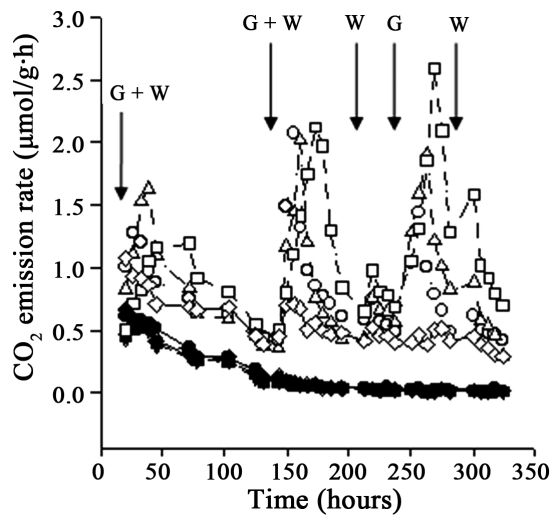

(a)

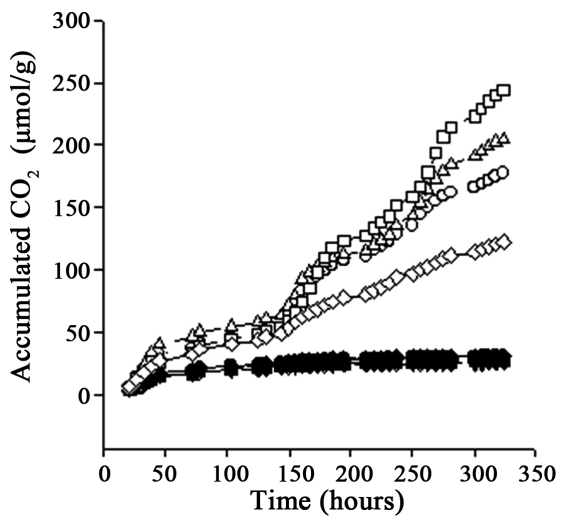

(b)

Figure 1. Respirometric analyses of municipal solid waste compost in response to doses of gasoline. (a) Rate of $\mathrm{CO}_{2}$ emission; (b) Cumulative $\mathrm{CO}_{2}$ emission. $7500 \mathrm{mg} \cdot \mathrm{kg}^{-1}$ gasoline ; $7500 \mathrm{mg} \mathrm{mL} \mathrm{kg}{ }^{-1}$ gasoline and humidity adjustment $\bigcirc ; 15,000 \mathrm{mg} \cdot \mathrm{kg}^{-1}$ gasoline $\boldsymbol{\nabla} ; 15,000 \mathrm{mg} \cdot \mathrm{kg}^{-1}$ gasoline and humidity adjustment $\nabla ; 37,500 \mathrm{mg} \cdot \mathrm{kg}^{-1}$ gasoline $\square$; $37,500 \mathrm{mg} \cdot \mathrm{kg}^{-1}$ gasoline and humidity adjustment $\square$; control $\diamond$; control and humidity adjustment $\diamond$. Arrows indicate the episodes of gasoline addition (G) and moisture correction $(\mathrm{W})$.

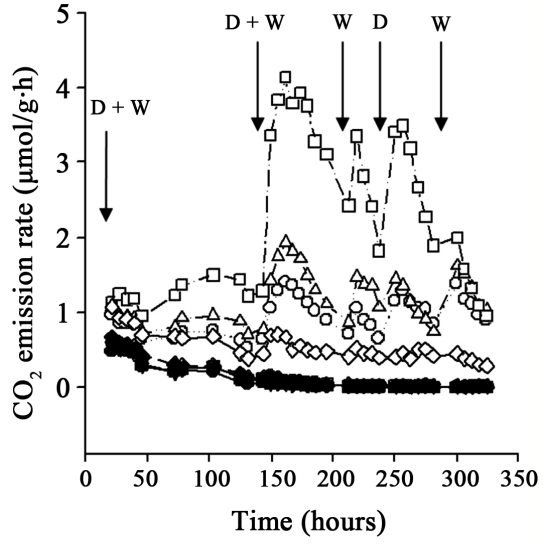

(a)

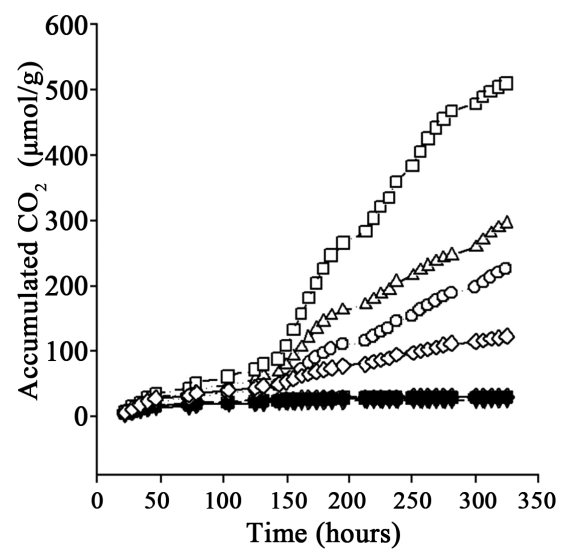

(b)

Figure 2. Respirometric analysis of municipal solid waste compost in response to doses of doses diesel. (a) Rate of $\mathrm{CO}_{2}$ emission; (b) Cumulative $\mathrm{CO}_{2}$ emission. $8500 \mathrm{mg} \cdot \mathrm{kg}^{-1}$ diesel oil $\bigcirc 8500 \mathrm{mg} \cdot \mathrm{kg}^{-1}$ diesel oil and humidity adjustment $\bigcirc ; 17,000 \mathrm{mg} \cdot \mathrm{kg}^{-1}$ diesel oil $\boldsymbol{\nabla}$; $17,000 \mathrm{mg} \cdot \mathrm{kg}^{-1}$ diesel oil and humidity adjustment $\nabla ; 42,650 \mathrm{mg} \cdot \mathrm{kg}^{-1}$ diesel oil $\square$; $42,650 \mathrm{mg} \cdot \mathrm{kg}^{-1}$ diesel oil and humidity adjustment $\square$; control $\diamond$; control and humidity adjustment $\diamond$. Arrows indicate the episodes of diesel addition (D) and moisture correction $(\mathrm{W})$. 
gasoline or diesel on $\mathrm{CO}_{2}$ emission rate (Figure 1(a) and Figure 2(a)) and accumulated $\mathrm{CO}_{2}$ (Figure 1(b) and Figure 2(b)) was observed only in treatments with moisture control. The highest accumulated $\mathrm{CO}_{2}$ concentration was obtained with the highest dose of both gasoline and diesel. Thus, the doses of $37,500 \mathrm{mg} \cdot \mathrm{kg}^{-1}$ (gasoline) or $42,650 \mathrm{mg} \cdot \mathrm{kg}^{-1}$ (diesel) and moisture adjustment were adopted for the next phase of production of inoculants.

\subsection{Heterotrophic Bacteria Densities}

After the initial application of fuels to MSWC, an adaptation/selection stage was observed in the early days of development of inoculum (Figure 3). This phase lasted for 12 and 8 days for inoculants receiving gasoline and diesel, respectively, which was followed by a rapid growth of cultivable heterotrophic bacterial populations.

Reducing the hydrocarbon application interval (inoculants A) increased the population of cultivable heterotrophicbacteria (Figure 3 ). The population of heterotrophic bacteria in compost (control) remained constant throughout the incubation period.

\subsection{Fatty Acids Profiles}

During the fatty acids profiling of microbial communities, we found that the procedure for hydrocarbon removal prior to EL-FAME extraction was effective only for gasoline treatments (Figure 4). Due to the impossibility to remove hydrocarbon interference on EL-FAME profiles of diesel-treated MSWC, fatty acid profile is shown only for gasoline-treated MSWC.

Cluster analysis of fatty acid profiles showed no differences between the result of day 0 and 3 (data not shown), indicating that, in this period, the composition of the microbial community did not change significantly in response to the application of gasoline. The result is consistent with the heterotrophic populations

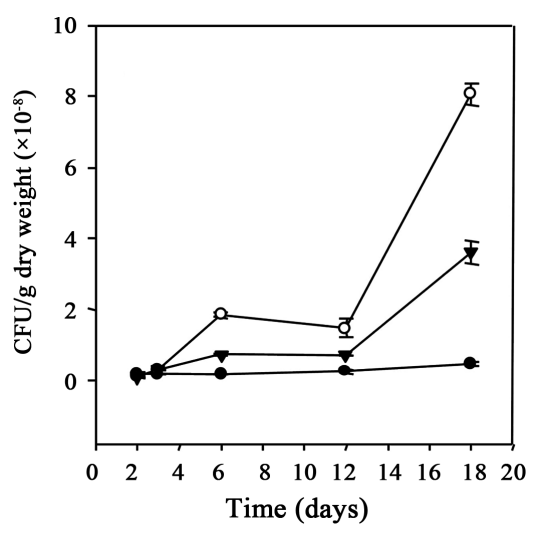

(a)

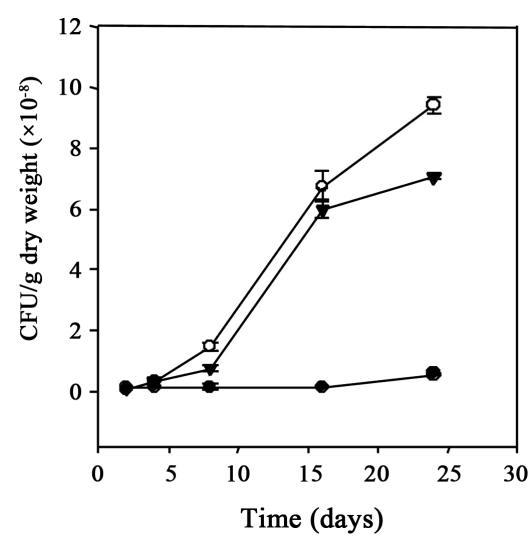

(b)

Figure 3. Density of cultivable heterotrophic bacteria during the development of the inoculants. Control ( ); Inoculant A $(\bigcirc)$; Inoculant B $(\boldsymbol{\nabla})$. In inoculant A, the application of hydrocarbons occurred every 3 days for gasoline and 4 days for diesel. In inoculant B, this interval was 6 days for gasoline and 8 days for diesel. (a) Gasoline; (b) Diesel. 


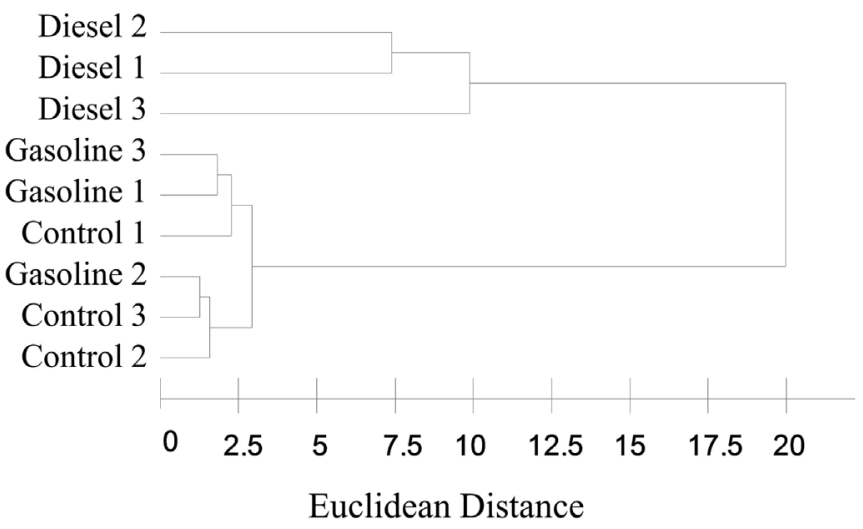

Figure 4. Dendrogram of ester-linked fatty acids methyl esters (EL-FAME) profiles after extraction of fuel from the MSWC with hexane. The numbers 1, 2, and 3 represent replicates of each sample. The profiles of gasoline-treated MSWC grouped with the control after hydrocarbon removal by hexane is shown. The profiles of diesel-treated MSWC formed a separate group, due to hydrocarbon interference.

count data (Figure 3(a)). We therefore decided to evaluate the profiles only at 0 , 6,12 , and 18 days of incubation (Figure 5).

The principal component analysis (PCA) of EL-FAME profiles show the influence of both gasoline and incubation period (Figure 5). The samples analyzed immediately after the addition of gasoline (AG and BG) grouped (Group I) with the control (fertilized compost without gasoline) collected at the onset of the experiment (C) and at 18 days (C.18d), and with the original unfertilized compost (Compost). EL-FAME profiles of gasoline-treated MSWC collected at 6 and 12 days after application of gasoline also grouped (Groups II and III) with their respective controls (C.6d and C.12d). EL-FAME profiles of gasoline-treated samples at 18 days grouped together (Group IV), but not with their respective control, which grouped with samples of Group I. The result of fatty acid profiles is consistent with the total heterotrophic plate count data (Figure 3(a)), which point to more significant differences between samples taken at 18 days as compared between themselves and with their control. The control at 18 days grouped with the control taken at the onset of the experiment $(\mathrm{C})$ and with unfertilized compost (Compost) (Group I), but not with the controls taken at 6 and 12 days. The result indicates that the microbial flora of the compost responded temporally to the addition of mineral nutrients applied during the preparation of the substrate, which induced significant changes in the community profile between days 0 and 12. After 18 days, the effect of the added nutrients on the microbial community was no longer evident.

The addition of nutrients and water did not affect the relative proportion of fatty acid markers of microbial groups (Figure 6(a) and Figure 6(b)). The relative proportion of fatty acid markers in the control throughout the incubation period (Figure 6(b)) was similar to the proportion in the unamended MSWC (Figure 6(a)). In treatments with gasoline (inoculants $a$ and $b$ ), a reduction in the amount of fatty acids of gram-positive bacteria and fungi and an increase in 


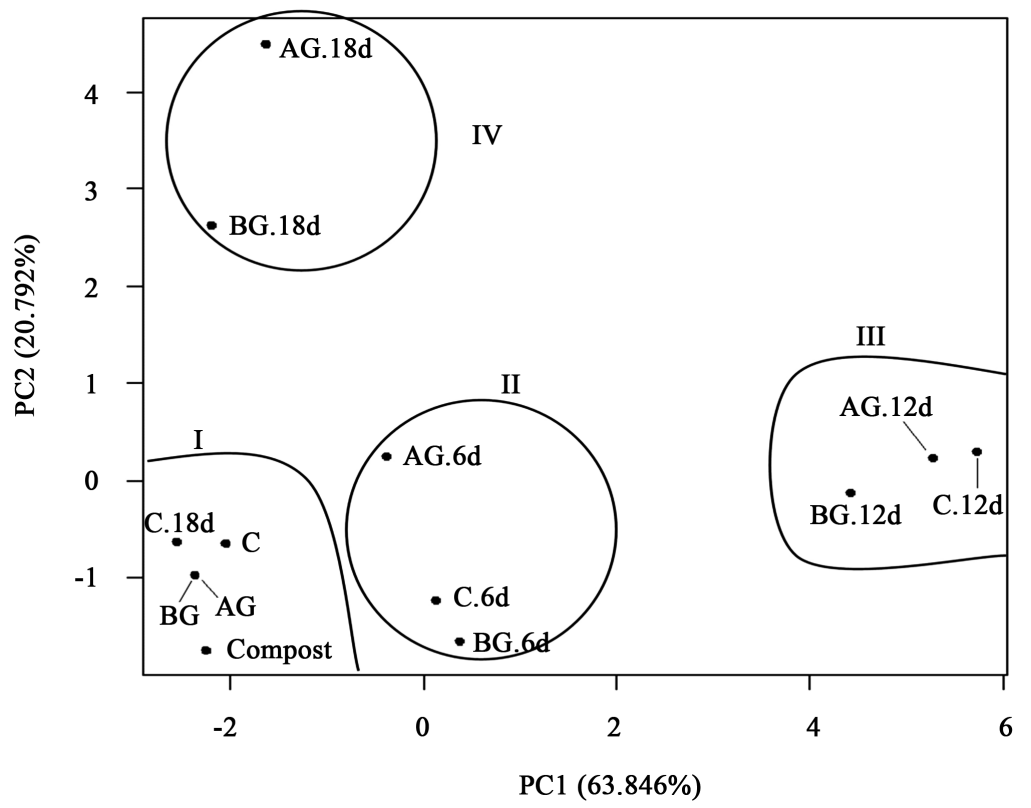

Figure 5. Principal component analysis of fatty acid methyl esters profiles (FAME) during the development of gasoline-enriched inoculants. C: unfertilized compost; AG: Inoculant A (gasoline added at 3-days intervals); BG Inoculant B (gasoline added at 6-days intervals); Compost: unfertilized MSWC. Samples were analyzed at 0 (no indication), 6 (6 d), 12 (12 d), and 18 days ( $18 \mathrm{~d})$.
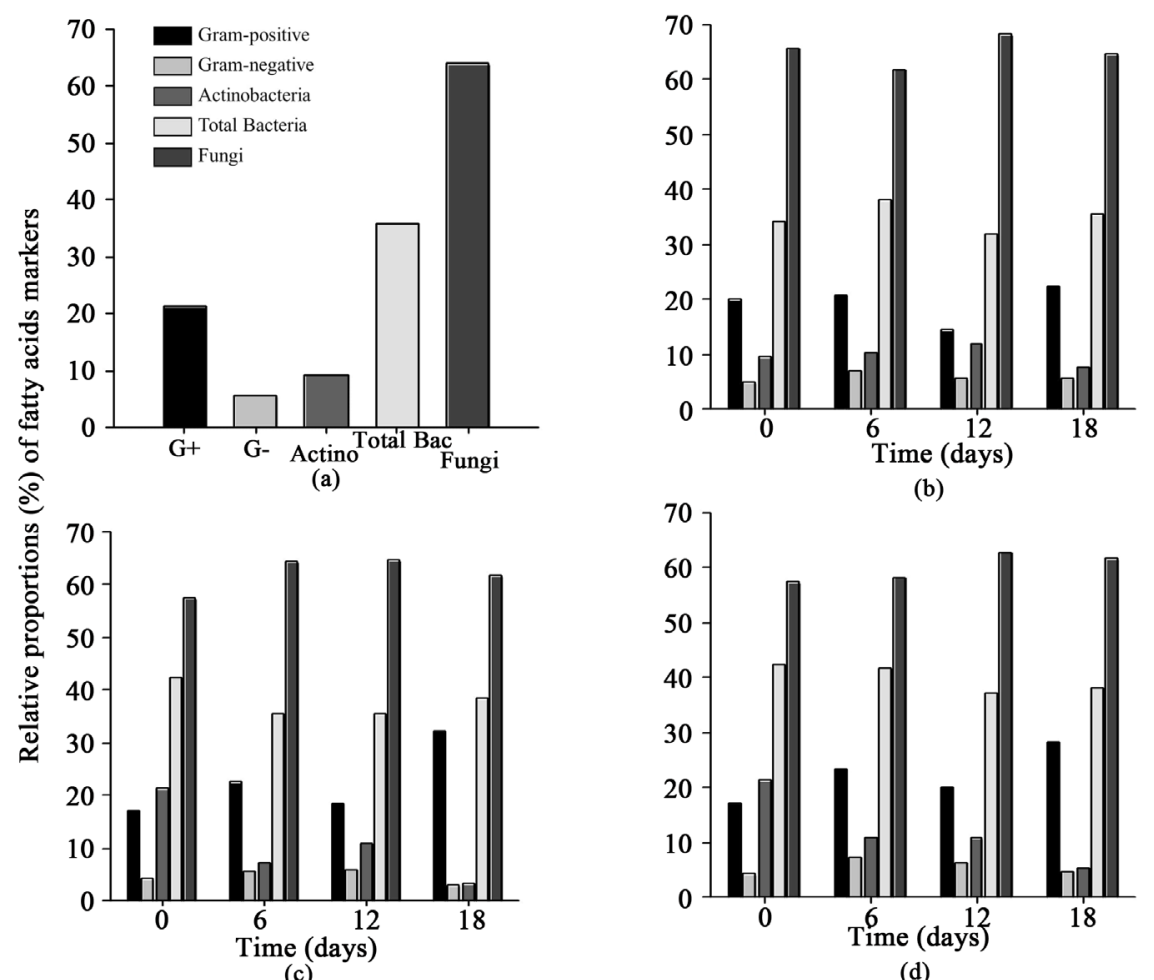

(b)

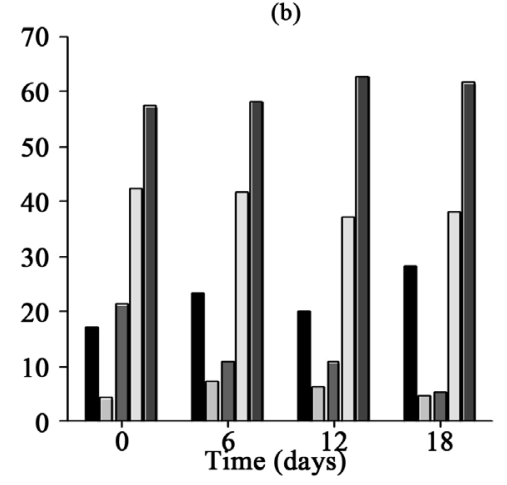

(d)

Figure 6. Relative proportions of fatty acids markers for microbial groups. G+: Gram-positive bacteria; G-: Gram-negative bacteria; Actino: actinobacteria; Bac total: total bacteria. (a) unfertilized MSWC; (b) control (fertilized MSWC); (c) inoculant A (gasoline added at 3-days intervals); (d) inoculant B (gasoline added at 6-days intervals). 
the fatty acid markers of actinobacteria ( $>2.3$-fold) and total bacteria (relative to control) occurred immediately after the addition of gasoline (Figure 6(c) and Figure 6(d)).

The PCA analysis showed that the EL-FAME profiles of the control and inoculant B were more similar between each other than with inoculant A (see Group II in Figure 5). This difference can be attributed to the frequency of gasoline addition to the inoculants. By day 6, inoculant A had received two application of gasoline (one at the onset of the experiment and a second one at day 3 ), while inoculant $B$ received only one application. This may have caused greater disturbance in the microbial community associated with inoculant A. Such disturbance is reflected in the increase of fatty acid markers of gram-positive bacteria and reduction of the markers of gram-negative and actinobacteria, as compared to the control (Figure 6(b) and Figure 6(c)).

Group III in the PCA analysis, which is formed by samples taken at day 12, showed the greatest difference in fatty acid profiles, as compared to the other groups (Figure 5). This result was somehow unexpected, because greatest differences in the numbers of heterotrophic bacteria were observed only at day 18 (Figure 3). Moreover, even considering that a significant change in the proportion of microbial populations may occur without any noticeable change in total microbial numbers, it remains intriguing that even the control at day 12 grouped together with gasoline-treated inoculants and way from the controls collected in other periods. Furthermore, as can be seen in Figure 3, heterotrophic counts in the control remained virtually unchanged throughout the incubation period. Thus, the reason for control at day 12 grouping away from other controls and together with inoculants A and B is unknown.

Fatty acid profiles of inoculants taken at day 18 were similar to those of inoculants at the onset of the experiment, suggesting an adaptation of the microbial community to the presence of gasoline and a great resilience of the microbial community (Figure 5). At this stage, the proportion of markers of gram-positive bacteria increased, while those of gram-negative bacteria and actinobacteria decreased, especially in inoculant A (Figure 6(c) and Figure 6(d)). The decrease in the numbers of markers of actinobacteria was also observed in the control (Figure 6(b)).

\section{Discussion}

Respirometryhas been used to study the degradation of contaminants and to provide information on the availability and toxicity of these molecules to microbial populations, as well as the limitation of nutrients, electron acceptors, and adequacy of other environmental factors during the degradation process [30] [31] [32] [33] [34]. The mineralization rate of contaminants can also be evaluated by measuring the $\mathrm{CO}_{2}$ production [35] [36]. In this study, respirometry was used to establish the best concentration of gasoline and diesel for the enrichment of hydrocarbonoclastic microbial populations in MSWC. 
Moisture adjustments as well as re-application of gasoline or diesel led to an increase in $\mathrm{CO}_{2}$ emission. Revolving the inoculants during these episodes may have also contributed to the increase in $\mathrm{CO}_{2}$ emission by providing oxygenation of anaerobic micro-habitats [37] and better exposure of the hydrocarbon molecules to the microorganisms [32].

Exposure of microbial communities to a contaminant induces the selection and physiological adaptation of microorganisms capable of metabolizing it [38]. Successive applications of gasoline or diesel to MSWC induced a rapid catabolic response of microorganisms, indicating the enrichment of hydrocarbonoclastic populations. $\mathrm{CO}_{2}$-emission rate was dose-dependent, indicating that organic carbon was the limiting factor for microbial growth in matured MSWCs.

We observed a slow growth rate of cultivable heterotrophic populations in MSWCs after application of diesel, which lasted for 8 days. This phase was followed by a rapid increase in the microbial counts and, as also occurred with $\mathrm{CO}_{2}$-emission, it was dose-dependent. The same was observed with gasoline treatments but, in this case, the slow growth rate phase lasted for 12 days. This extended "lag" phase may be related to the presence of lighter hydrocarbons in gasoline, which are more toxic to microorganisms [39]. Therefore, induction of tolerance mechanisms may be required to withstand the presence of light hydrocarbons, leading to a prolonged lag phase. This toxic effect of gasoline was also observed by Osterreicher-Cunha et al. (2009) [40] in their study of soil bacterial populations. They found that the toxicity of gasoline was more prolonged in gasoline treatments with the addition of ethanol-the same type of gasoline used in this study (24\% v/v ethanol).

In Brazilian gasoline, monoaromatic hydrocarbons benzene, toluene and xylene (BTEX), as well as ethanol, contribute to its toxicity to microbial populations. Due to the lipophilicity of these monoaromatic molecules and the relatively high water solubility (which is increased in the presence of ethanol), they accumulate in the citoplasmic membrane of the cells, causing nonspecific permeabilization of this structure [41] [42] [43] [44] [45]. Thus, these compounds interfere with membrane integrity as well as in their role as a selective barrier, as a matrix for enzymes and as an energy transducer [42] [43].

Various mechanisms of tolerance to hydrocarbons have been described, such as decrease in the membrane fluidity by modifying the cis configuration to the trans-unsaturated fatty acids [41] [46] [47] or saturation of the acyl chains of fatty acids [48]; reducing cell wall hydrophobicity via changes in the outer membrane polysaccharides in Gram-negative bacteria [41] [43] [48] [49] and active transportof contaminants to the outside of cells [41]; loss of porins, which diminishes the transport of hydrocarbons to the inner side [50]; and increased cell size, which reduces its surface area and thereby reduces the binding of toxic compounds to its surface [51]. The microbial community of the compost did not rely on isomerization of unsaturated fatty acids as a mechanism of tolerance to gasoline, since the analysis of EL-FAMEs did not show the presence of 
trans-fatty acids (data not shown). Therefore, other mechanisms of adaptation must have been employed by the members of the microbial communities.

Studies have shown that Gram-negative bacteria are more tolerant to lipophilic compounds than gram-positive bacteria, since changes in their outer membrane decrease their hydrophobicity and therefore repels these hydrophobic compounds [43] [47] [49]. However, we observed that the fatty acid markers for gram-negative bacteria decreased significantly after the addition of gasoline to the MSWC; the inverse occurred with the markers for gram-positive bacteria. We thus conclude that, in complex microbial communities, a number of different strategies may be involved in microbial adaptation to hydrocarbon toxicity, and one single mechanism of tolerance cannot explain the comportment of mixed microbial populations challenged with hydrocarbon toxicity.

The prevalence of gram-positive bacteria, including actinobacteria, over gram-negative bacteria in uncontaminated MSWC was expected, since the former are more resistant to high temperatures, which characterizes the thermophilic stage during composting. Amir et al. (2008) [52] found that fatty acid markers for fungi are dominant in the maturity phase of composting, which is in agreement with our results.

Microorganisms have different survival strategies for adapting to environmental conditions prevailing in their habitats. The r-strategists are characterized by high growth rates and high metabolic activity when substrate is abundant [53]. On the other side, K-strategists rely on efficient substrate utilization, slow growth rate, and low metabolic activity to thrive in their ecological niches [53] [54]. For bioaugmentation in sites subjected to sporadic contamination, using an inoculant enriched in $\mathrm{r}$-strategists may be advantageous, since high-contaminant concentrations stimulate their rapid growth and metabolic activity, resulting in rapid elimination of the contaminants [53]. However, K-strategists may be important in the final stages of bioremediation, when contaminant availability is reduced and, in case of mixed pollutants, the residual contaminants tend to be structurally more complex and recalcitrant. Gram-negative bacteria are generally regarded as r-strategists, whereas gram-positive are K-strategists. However, it has been shown that some bacteria, such as Bacillus sp., can change their survival strategy, depending on the environmental conditions [55]. Accordingly, the isolate Rhodococcusrhodochrous TRN7, a gram-positive bacteria isolated by Rodrigues et al. (2015) [56], demonstrated the ability to grow rapidly on several different hydrocarbons as the only source of carbon and energy, including high and low molecular weight hydrocarbons and PAHs, such as toluene, pentacontane, and anthracene.

\section{Conclusion}

Our study showed that members of the microbial community present in matured municipal solid waste compost (MSWC) could degrade the hydrocarbons present in gasoline and diesel. Moisture is a limiting factor for microbial activity 
in MSWC contaminated with these fuels. During the production of inoculants, populations of cultivable bacteria adapted more rapidly to diesel than to gasoline. Adding hydrocarbons to the compost alters the fatty acid profile of the microbial community. The fungal community predominates over other microbial groups, while gram-positive bacteria are favored by hydrocarbons and gram-negative bacteria are inhibited by these molecules. Frequent controlled contamination of MSWC with diesel and gasoline was found to be efficient for the enrichment of hydrocarbonoclastic bacteria, which is a practical method for the production of microbial inoculants for the bioremediation of hydrocarbons with high microbial diversity. In biodegradation trials (data not shown), the inoculants were very efficient, removing over $99 \%$ of hydrocarbons from a heavy soil (73\% clay) contaminated with either diesel or gasoline $\left(17.000 \mathrm{mg} \cdot \mathrm{Kg}^{-1}\right.$ and $15.000 \mathrm{mg} \cdot \mathrm{Kg}^{-1}$, respectively). Inoculants based on MSWC enriched in hydrocarbonoclastic microorganisms may be an effective alternative to improve bioremediation in hydrocarbon-contaminated soils.

\section{References}

[1] Röling, W.F.M., Milner, M.G., Jones, D.M., Lee, K., Daniel, F., Swannell, R.J.P. and Head, I.M. (2002) Robust Hydrocarbon Degradation and Dynamics of Bacterial Communities during Nutrient-Enhanced Oil Spill Bioremediation. Applied and Environmental Microbiology, 68, 5537-5548.

https://doi.org/10.1128/AEM.68.11.5537-5548.2002

[2] Stroud, J.L., Paton, G.I. and Semple, K.T. (2007) Microbe-Aliphatic Hydrocarbon Interactions in Soil: Implications for Biodegradation and Bioremediation. Journal of Applied Microbiology, 102, 1239-1253. https://doi.org/10.1111/j.1365-2672.2007.03401.x

[3] Tyagi, M., da Fonseca, M.M. and de Carvalho, C.C. (2011) Bioaugmentation and Biostimulation Strategies to Improve the Effectiveness of Bioremediation Processes. Biodegradation, 22, 231-241. https://doi.org/10.1007/s10532-010-9394-4

[4] Dell'anno, A., Beolchini, F., Rocchetti, L., Luna, G.M. and Danovaro, R. (2012) High Bacterial Biodiversity Increases Degradation Performance of Hydrocarbons during Bioremediation of Contaminated Harbor Marine Sediments. Environmental Pollution, 167, 8-92. https://doi.org/10.1016/j.envpol.2012.03.043

[5] Cerqueira, V.S., Peralba, M.C.R., Camargo, F.A.O. and Bento, F.M. (2014) Comparasion of Bioremediation Strategies for Soil Impacted with Petrochemical Oily Sludge. International Biodeterioration \& Biodegradation, 95, 338-345. https://doi.org/10.1016/j.ibiod.2014.08.015

[6] Mnif, I., Mnif, S., Sahnoun, R., Martouf, S., Ayedi, Y., Ellouze-Chaabouni, S. and Ghribi, D. (2015) Biodegradation of Diesel Oil by a Novel Microbial Consortium: Comparison between Co-Inoculation with Biosurfactants-Producing Strain and Exogenously Added Biosurfactants. Environmental Science and Pollution Research, 22, 14852-14861. https://doi.org/10.1007/s11356-015-4488-5

[7] Carmichael, L.M. and Pfaender, F.K. (1997) The Effect of Inorganic and Organic Supplements on the Microbial Degradation of Phenanthrene and Pyrene in Soils. Biodegradation, 8, 1-13. https://doi.org/10.1023/A:1008258720649

[8] Straube, W.L., Jones-Meehan, J., Pritchard, P.H. and Jones, W.R. (1999) Bench-Scale Optimization of Bioaugmentation Strategies for Treatment of Soils 
Contaminated with High Molecular Weight Polyaromatic Hydrocarbons. Resources, Conservation and Recycling, 27, 27-37. https://doi.org/10.1016/S0921-3449(98)00083-4

[9] Gogoi, B.K., Dutta , N.N., Goswami, P. and Mohan, T.R.K. (2003) A Case Study of Bioremediation of Petroleum-Hydrocarbon Contaminated Soil at a Crude Oil Spill Site. Advances in Environmental Research, 7, 767-782. https://doi.org/10.1016/S1093-0191(02)00029-1

[10] Baptista, S.J., Cammarota, M.C. and Freire, D.D.C. (2005) Production of $\mathrm{CO}_{2}$ in Crude Oil Bioremediation in Clay Soil. Brazilian Archives of Biology and Technology, 48, 249-255. https://doi.org/10.1590/S1516-89132005000400031

[11] Jacques, R.J.S., Bento, F.M., Antoniolli, Z.I. and Camargo, F.A.O. (2007) Biorremediação de solos contaminados com hidrocarbonetos aromáticos policíclicos. Ciência Rural, 37, 1192-1201. https://doi.org/10.1590/S0103-84782007000400049

[12] Mariano, A.P., Kataoka, A.P.A.G., Angelis, D.F. and Bonotto, D.M. (2007) Laboratory Study on the Bioremediation of Diesel Oil Contaminated Soil from a Petrol Station. Brazilian Journal of Microbiology, 38, 346-353.

https://doi.org/10.1590/S1517-83822007000200030

[13] Wu, Y., Luo, Y., Zou, D., Ni, J., Liu, W., Teng, Y. and Li, Z. (2008) Bioremediation of Polycyclic Aromatic Hydrocarbons Contaminated Soil with Monilinia sp.: Degradation and Microbial Community Analysis. Biodegradation, 19, 247-257. https://doi.org/10.1007/s10532-007-9131-9

[14] Hassanshahian, M., Zeynalipour, M.S. and Musa, F.H. (2014) Isolation and Characterization of Crude Oil Degrading Bacteria from the Persin Gulf (Khorramshahr Provenance). Marine Pollution Bulletin, 82, 39-44. https://doi.org/10.1016/j.marpolbul.2014.03.027

[15] Gallego, J.L.R., Loredo, J., Llamas, J.F., Vázquez, F. and Sánchez, J. (2001) Bioremediation of Diesel-Contaminated Soils: Evaluation of Potential in Situ Techniques by Study of Bacterial Degradation. Biodegradation, 12, 325-335. https://doi.org/10.1023/A:1014397732435

[16] Trindade, P.V.O., Sobral, L.G., Rizzo, A.C.L., Leite, S.G.F. and Soriano, A.U. (2005) Bioremediation of a Weathered and a Recently Oil-Contaminated Soils from Brazil: A Comparison Study. Chemosfere, 58, 515-522. https://doi.org/10.1016/j.chemosphere.2004.09.021

[17] Ruberto, L., Dias, R., Balbo, L.O.A., Vazquez, S.C., Hernandez, E.A. and Mac Cormack, W.P. (2009) Influence of Nutrients Addition and Bioaugmentation on the Hydrocarbon Biodegradation of a Chronically Contaminated Antarctic Soil. Journal of Applied Microbiology, 106, 1101-1110. https://doi.org/10.1111/j.1365-2672.2008.04073.x

[18] Aburto-Medina, A., Adetutu, E.M., Aleer, S., Weber, J., Patil, S.S., Sheppard, P.J., Ball, A.S. and Juhasz, A.L. (2015) Comparison of Indigenous and Exogenous Microbial Populations during Slurry Phase Biodegradation of Long-Term Hydrocarbon-Contaminated Soil. Biodegradation, 23, 813-822. https://doi.org/10.1007/s10532-012-9563-8

[19] Sarkar, D., Ferguson, M., Datta, R. and Birnbaum, S. (2000) Bioremediation of Petroleum Hydrocarbons in Contaminated Soils: Comparison of Biosolids Addition, Carbon Supplementation, and Monitored Natural Attenuation. Environmental Pollution, 136, 187-195. https://doi.org/10.1016/j.envpol.2004.09.025

[20] Tejada, M., Gonzalez, J.L., Hernandez, M.T. and Garcia, C. (2008) Application of Different Organic Amendments in a Gasoline Contaminated Soil: Effect on Soil 
Microbial Properties. Bioresource Technology, 99, 2872-2880. https://doi.org/10.1016/j.biortech.2007.06.002

[21] Ishii, K., Fukui, M. and Takii, S. (2000) Microbial Succession during a Composting Process as Evaluated by Denaturing Gradient Gel Electrophoresis Analysis. Journal of Applied Microbiology, 89, 768-777. https://doi.org/10.1046/j.1365-2672.2000.01177.x

[22] Namkoong, W., Hwang, E.Y., Park, J.S. and Choi, J.Y. (2002) Bioremediation of Diesel-Contaminated Soil with Composting. Environmental Pollution, 119, 23-31. https://doi.org/10.1016/S0269-7491(01)00328-1

[23] Steger, K., Jarvis, A., Sven, S. and Sundh, I. (2003) Comparison of Signature Lipid Methods to Determine Microbial Community Structure in Compost. Journal of Microbiological Methods, 55, 371-382. https://doi.org/10.1016/S0167-7012(03)00187-8

[24] Schutter, M.E. and Dick, R.P. (2000) Comparison of Fatty Acid Methyl Ester (FAME) Methods for Characterizing Microbial Communities. Soil Science Society of America Journal, 64, 1659-1668. https://doi.org/10.2136/sssaj2000.6451659x

[25] Kato, K. and Miura, N. (2008) Effect of Matured Compost as a Bulking and Inoculating Agent on the Microbial Community and Maturity of Cattle Manure Compost. Bioresource Technology, 99, 3372-3380. https://doi.org/10.1016/j.biortech.2007.08.019

[26] Klamer, M. and Baath, E. (1998) Microbial Community Dynamics during Composting of Straw Material Studied using Phospholipid Fatty Acid Analysis. FEMS Microbiology Ecology, 27, 9-20. https://doi.org/10.1111/j.1574-6941.1998.tb00521.x

[27] Steger, K., Jarvis, A., Vasara, T., Romantschuk, M. and Sundh, I. (2007) Effects of Differing Temperature Management on Development of Actinobacteria Populations during Composting. Research in Microbiology, 158, 617-624. https://doi.org/10.1016/j.resmic.2007.05.006

[28] Steger, K., Eklind, Y., Olsson, J. and Sundh, I. (2005) Microbial Community Growth and Utilization of Carbon Constituents during Thermophilic Composting at Different Oxygen Levels. Microbial Ecology, 50, 163-171. https://doi.org/10.1007/s00248-004-0139-y

[29] O’Leary W.M. and Wilkinson S.G. (1988) Gram-Positive Bacteria. In: Ratledge, C. and Wilkinson, S.G., Eds., Microbial Lipids, Academic Press, London, 117-201.

[30] Eisentraeger, A., Maxam, G., Rila, J.P. and Dott, W. (2000) A Stepwise Procedure for Assessment of the Microbial Respiratory Activity of Soil Samples Contaminated with Organic Compounds. Ecotoxicology and Environmental Safety, 47, 65-73. https://doi.org/10.1006/eesa.2000.1933

[31] Miles, R.A. and Doucette, W.J. (2001) Assessing the Aerobic Biodegradability of 14 Hydrocarbons in Two Soils using a Simple Microcosm/Respiration Method. Chemosfere, 45, 1085-1090. https://doi.org/10.1016/S0045-6535(01)00012-1

[32] Semple, K.T., Dew, N.M., Doick, K.J. and Rhodes, A.H. (2006) Can Microbial Mineralization Be Used to Estimate Microbial Availability of Organic Contaminants in Soil? Environmental Pollution, 140, 164-172. https://doi.org/10.1016/j.envpol.2005.06.009

[33] Montagnolli, R.I., Lopes, P.R.M. and Bidoia, E.D. (2015) Assessing Bacillus subtilis biosurfactants Effects on the Biodegradation of Petroleum Products. Environmental Monitoring and Assessment, 187, 4116. https://doi.org/10.1007/s10661-014-4116-8

[34] Olanipekun, O.O., Ogumbayo, A.O., Nwachukwu, S.C.U. and Bello, R.A. (2015) 
Comparative Study of Microbial Activities and Biodegraadtion-Abilities of Undefined Consortium in Some Hydrocarbon Contaminated Sites in the Niger Delta, Nigeria. Journal of Environmental Protection, 6, 138-145.

https://doi.org/10.4236/jep.2015.62016

[35] Aspray, T.J., Carvalho, D.J.C. and Philp, J.C. (2007) Application of Soil Slurry Respirometry to Optimise and Subsequently Monitor ex Situ Bioremediation of Hydrocarbon-Contaminated Soils. International Biodeterioration \& Biodegradation, 60, 279-284. https://doi.org/10.1016/j.ibiod.2007.04.004

[36] Al-Saleh, E. and Akbar, A. (2015) Occurrence of Pseudomonas aeruginosa in Kuwait Soil. Chemosphere, 120, 100-107. https://doi.org/10.1016/j.chemosphere.2014.06.031

[37] Megharaj, M., Ramakrishnan, B., Venkateswarlu, K., Sethunathan, N. and Naidu, R. (2011) Bioremediation Approaches for Organic Pollutants: A Critical Perspective. Environment International, 37, 1362-1375. https://doi.org/10.1016/j.envint.2011.06.003

[38] Sanni, G.O., Coulon, F. and McGenity, T.J. (2015) Dynamics and Distribution of Bacterial and Archaeal Communities in Oil-Contaminated Temperate Coastal Mudflat Mesocosms. Environmental Science and Pollution Research International, 22, 15230-15247. https://doi.org/10.1007/s11356-015-4313-1

[39] Labud, V., Garcia, C. and Hernandez, T. (2007) Effect of Hydrocarbon Pollution on the Microbial Properties of a Sandy and a Clay Soil. Chemosphere, 66, 1863-1871. https://doi.org/10.1016/j.chemosphere.2006.08.021

[40] Osterreicher-Cunha, P., Vargas, E.A.R., Guimarãoes, J.R.D., Lago, G.P., Antunes, F.S. and Silva, M.I.P. (2009) Effect of Ethanol on the Biodegradation of Gasoline in an Unsaturated Tropical Soil. International Biodeterioration \& Biodegradation, 63, 208-216. https://doi.org/10.1016/j.ibiod.2008.09.004

[41] Isken, S. and Bont, J.A.M. (1996) Active Efflux of Toluene in a Solvent-Resistant Bacterium. Journal of Bacteriology, 178, 6056-6058. https://doi.org/10.1128/jb.178.20.6056-6058.1996

[42] Isken, S. and Bont, J.A.M. (1998) Bacteria Tolerant to Organic Solvents. Extremophiles, 2, 229-238. https://doi.org/10.1007/s007920050065

[43] Ramos, J.L., Duque, E., Gallegos, M.T., Godoy, P., Ramos-González, M.I., Rojas, A., Terán, W. and Segura, A. (2002) Mechanisms of Solvente Tolerance in Gram-Negative Bactéria. Annual Review of Microbiology, 56, 743-768. https://doi.org/10.1146/annurev.micro.56.012302.161038

[44] Duldhardt, I., Nijenhuis, I., Schauer, F. and Heipieper, H.J. (2007) Anaerobically Grown Thauera aromatica, Desulfococcus multivorans, Geobacter sulfurreducens Are More Sensitive towards Organic Solvents than Aerobic Bacteria. Applied Microbiology and Biotechnology, 77, 705-771. https://doi.org/10.1007/s00253-007-1179-2

[45] Udaondo, Z., Molina, L., Daniels, C., Gómez, M.J., Molina-Henares, M.A., Matilla, M.A., Roca, A., Fernández, M., Duque, E., Segura, A. and Ramos, J.L. (2013) Metabolic Potential of the Organic-Solvent Tolerant Pseudomonas putida DOT-T1E Deduced from Its Annotated Genome. Microbial Biotechnology, 6, 598-611. https://doi.org/10.1111/1751-7915.12061

[46] Heipieper, J.H. and Bont, J.A.M. (1994) Adaptation of Pseudomonas putida S12 to Ethanol and Toluene at the Level of Fatty Acid Composition of Membranes. Applied and Environmental Microbiology, 60, 4440-4444.

[47] Ramos, J.L., Cuenca, M.S., Molina-Santiago, C., Segura, A., Duque, E., 
Gómez-García, M.R., Udaondo, Z. and Roca, A. (2015) Mechanisms of Solvente Resistance Mediated by Interplay of Cellular Factors in Pseudomonas putida. FEMS Microbiology Reviews, 39, 555-566. https://doi.org/10.1093/femsre/fuv006

[48] Sikkema, J., Bont, J.A.M. and Poolman, B. (1995) Mechanisms of Membrane Toxicity of Hydrocarbons. Microbiological Reviews, 59, 201-222.

[49] Uhl, J., Hein, E.M., Hayen, H., Schmid, A. and Blank, L.M. (2012) The Glycerophospholipid Inventory of Pseudomonas putida Is Conserved Etween Strains and Enables Growth Condition-Related Alterations. Microbial Biotechnology, 5, 45-58.

[50] Aono, R. and Kobayashi, H. (1997) Cell Surface Properties of Organic Solvent-Tolerant Mutants of Escherichia coli K-12. Applied and Environmental Microbiology, 63, 3637-3642.

[51] Neumann, G., Veeranagouda, Y., Karegoudar, T.B., Sahin, O., Mäusezahl, M., Nadja, K., Kappelmeyer, U. and Heipieper, H.J. (2005) Cells of Pseudomonas putida and Enterobacter sp. Adapt to Toxic Organic Compounds by Increasing Their Size. EXtremophiles, 9, 163-168. https://doi.org/10.1007/s00792-005-0431-x

[52] Amir, S., Merlina, G., Pinelli, E., Wintertonc, P., Revel, J.C. and Hafidid, M. (2008) Microbial Community Dynamics during Composting of Sewage Sludge and Straw Studied through Phospholipid and Neutral Lipid Analysis. Journal of Hazardous Materials, 159, 593-601. https://doi.org/10.1016/j.jhazmat.2008.02.062

[53] Thompson, I.P., Van Der Gast, C.J., Ciric, L. and Singer, A.C. (2005) Bioaugmentation for Bioremediation: The Challenge of Strain Selection. Environmental Microbiology, 7, 909-915. https://doi.org/10.1111/j.1462-2920.2005.00804.x

[54] Margesin, R., Hämmerle, M. and Tscherko, D. (2007) Microbial Activity and Community Composition during Bioremediation of Diesel-Oil-Contaminated Soil: Effects of Hydrocarbon Concentration, Fertilizers, and Incubation Time. Microbial Ecology, 53, 259-269. https://doi.org/10.1007/s00248-006-9136-7

[55] Golovlev, E.L. (2001) Ecological Strategy of Bacteria: Specific Nature of the Problem. Microbiology, 70, 379-383. https://doi.org/10.1023/A:1010476507199

[56] Rodrigues, E.M., Kalks, K.H.M. and Tótola, M.R. (2015) Prospect, Isolation, and Characterization of Microorganisms for Potential Use in Cases of Oil Boiremediation along the Coast of Trindade Island, Brazil. Journal of Environmental Management, 156, 15-22. https://doi.org/10.1016/j.jenvman.2015.03.016 